POLLACK PERIODICA

An International Journal for Engineering and Information Sciences

DOI: $10.1556 / 606.2018 .13 .1 .13$

Vol. 13, No. 1, pp. 145-156 (2018)

www.akademiai.com

\title{
INVESTIGATION OF HYDRAULIC REGIME AT MIDDLE PART OF THE LOIRE RIVER IN CONTEXT OF FLOODS AND LOW FLOW EVENTS
}

\author{
${ }^{1}$ Alban KURIQI, ${ }^{2}$ Mehmet ARDIÇLIOĞLU \\ ${ }^{1}$ Illyrian Consulting Engineers sh.p.k, Rr. Andon Zako Cajupi, Nd. 14, H. 14, Ap. 2 \\ 1019 Tirana, Albania, e-mail: albankuriqi@gmail.com \\ ${ }^{2}$ Civil Engineering Department, Engineering Faculty, Erciyes University \\ 38039, Kayseri, Turkey, e-mail: mardic@erciyes.edu.tr
}

Received 1 May 2017; accepted 14 September 2017

\begin{abstract}
Significant variability characterizes natural streams in space and time that describe hydraulic regime of the entire stream. In this paper, the importance of investigation and assessment of hydraulic system in the context of management of surface water resources is discussed. The objective of this study is to investigate hydraulic regime in the middle part of Loire River located in France. Loire River basin is the largest river basin in France and origin of many potential flood events. Investigation of a hydraulic regime of the Loire River is conducted using traditional hydraulic simulation model HEC-RAS. Hydraulic modeling of the river is carried out by considering two different datasets (i.e. flood and low flow events). A certain number of hydraulic structures, which have the significant effect on the hydraulic regime of the river, is considered as well. Through Froude number computation, it is noticed that middle part of the Loire River demonstrates subcritical regime. Accurate calibration and validation of the model are performed by changing Manning coefficient along the riverbed. Computation carried out for both data sets; show that there are no big differences between observed and simulated water levels, results obtained are satisfactory. Therefore, to get more accurate information about the hydraulic regime at the middle part at of Loire River, the further simulation needs to be done by considering an additional dataset of floods and low flow events.
\end{abstract}

Keywords: Loire River, HEC-RAS, Hydraulic regime, Floods, Low flow

\section{Introduction}

Flow discharge in a natural stream has significant variance in time and space scale. Whereas, flow regime along a riverbed may change form, hour-to-hour, days to days and so on. To understand flow characteristics and hydraulic regime related to the natural 
stream, precise measurements are needed [1]-[4]. Therefore, management of water resources, especially surface water is a challenges task for engineers and stakeholders as well. In this context, assessment of design flood is the most important task in the hydrological study, regarding water resources project like; bridge, dam and culvert.

Natural hazard represented by floods events are revealing significant threat for inhabitants, while global damages due to climate change and floods have increased [5][8]. Therefore, even in the most complicated situation that could occur during the flood peak, the level of the hazard may be reduced with better management of the river basin. Many investigations and studies show that risk level or damage rate does not depend only on flood peak. In addition, the geomorphology of the flood plain and land use next to the river has a significant effect on flood magnitude amplification [9]-[12].

Concerning to the flood magnitude amplification, climate conditions have a major role, since heavy rainfall leads to the increments of the reservoir water level and also a possible overtopping failure of retaining structures [13]-[16]. Many studies in the field of hydraulic and hydrology, involving especially dam breach are used to determine hazard index in the framework of the life-safety, economics, environmental and cultural loose [17]. In this paper, the hydraulic regime at the middle part of the Loire River in the case of floods and low flow events is discussed. Loire River is the largest river basin in France; it is about $1020 \mathrm{~km}$ long, and a total area of the catchment is about $117000 \mathrm{~km}^{2},[18]$.

The Loire is a source of many potential flooding during the wet period (i.e. spring season), while during the dry period (i.e. summer season) significant decrements of water level occur [19], [20]. Loire River basin is divided into 68 sub-catchments (Fig. 1), with an average size of each sub-catchment around $2000 \mathrm{~km}^{2}$.

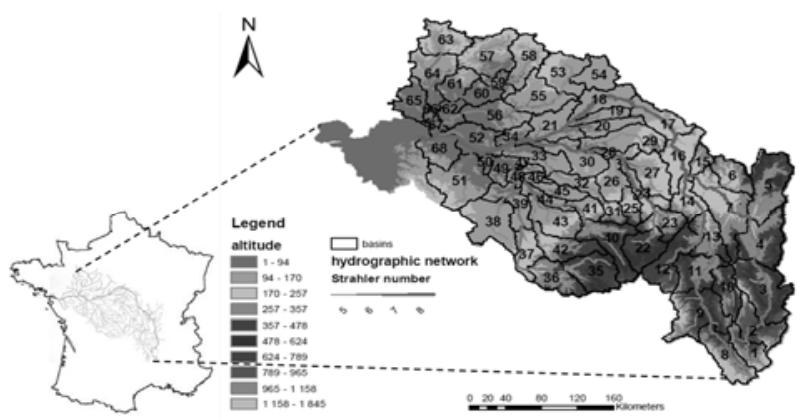

Fig. 1. Loire river basin with 68-delineation sub-catchment after [21]

\section{Materials and methods}

For modeling and investigating of the hydraulic behavior of the Loire River the following data set is used:

a) Hydraulic models are carried out in HEC-RAS;

b) Topographical information for the river cross sections; 
c) The list of bridges and other structures located in Nevers and Villerest municipality.

In addition, flow data and water levels obtained from the sections regarding records done during the following years; 2008-2009 and 2011-2012.

There are two different methods for estimation of the seasonal and annual discharge behavior of rivers:

1) Flow data analysis

2) Mathematical models, [22].

The first method is based mostly on statistical analysis of the hydro-meteorological data records, while the second one takes into account empirical relations between maximum flow (i.e. floods) and geomorphological characteristics of the river basin [23]. In addition, there are many mathematical models used for flood prediction and propagation, among them Rainfall-Runoff (RR), which is still seldom used because of the lack of accuracy [24]. In this study as mentioned above, the well-known mathematical model is used (i.e. HEC-RAS) to perform certain unsteady gradually varied flow simulations. Mathematical model HEC-RAS is based on Saint-Venant equations (1), (2), which is also based on finite differences solutions [25], [26],

$$
\begin{aligned}
& \frac{\partial A}{\partial t}+\frac{\partial Q}{\partial x}=0 \\
& \frac{\partial Q}{\partial t}+\frac{\partial\left(Q^{2} / A\right)}{\partial x}+g A \frac{\partial H}{\partial x}+g A\left(S_{0}-S_{f}\right)=0,
\end{aligned}
$$

where $A\left[\mathrm{~m}^{2}\right]$ is the cross-section area; $Q\left[\mathrm{~m}^{3} / \mathrm{s}\right]$ is the discharge; $g\left[\mathrm{~m} / \mathrm{s}^{2}\right]$ is the gravitational acceleration; $H[\mathrm{~m}]$ is the water level; $S_{0}[\%]$ is the riverbed slope; $S_{f}[\%]$ is the energy slope; $t[\mathrm{~h}]$ is the temporal coordinate and $x[\mathrm{~m}]$ is the longitudinal coordinate. Flow in natural and open channels are described by considering simple cross section, one-dimensional hydraulic equation, but in reality, hydrodynamic processes in the natural river are quite complex. Therefore, one-dimensional flow is not proper assumption [27]. Whereas to avoid uncertainties' concerning to the transition phase between subcritical and supercritical flow, since finite differences method is limited, the mixed-flow routine is considered during the simulation [28]. In addition, to have a clear idea about the hydraulic behavior of the middle part of Loire River, except unsteady flow analysis and certain calibration, a steady flow analysis is performed. While particular calibration is made concerning to the Manning coefficients, for a different part of the river by also improving the initial geometry (i.e. interpolating sections, introducing necessary structures if necessary). Afterwards, the observed and simulated water level is compared. Firstly, the model is calibrated by considering the first set of the flow data and water levels regarding discharge measurements conducted on the year 2008. The calibration of Manning coefficient for steady flow is done starting from the downstream to back upstream part of the river. The relevant records of hydrometric data considered for validation of the model are obtained from certain number gauge stations. 
To achieve a proper setting of the model, it is necessary to define the criterion for model calibration. Therefore, sections implemented in the design that is closer to the gauge stations are calibrated. Therefore, it is deduced that differences between simulated water level $\left(H_{\text {sim }}\right)$ during the modeling and observed water level obtained from the set of given data $\left(H_{o b s}\right)$, is less or max. About to $10-30 \mathrm{~cm}$. Available information about the position of the gauge stations facilitated us to define the distance between them. For each segment of the river, the first step of the calibration procedure is changing the Manning coefficient of the riverbed and floodplain after that the validation for new geomorphological conditions. To remain consistent with the observed roughness of the riverbed, the Manning coefficient should not exceed more than 0.05 for the main channel or 0.06 if the riverbed is very meander [29].

As it is mentioned above, if the difference between simulated and observed elevation is less than 10 to $30 \mathrm{~cm}$ it is an indicator that Manning coefficient for a particular segment of the river is properly calibrated. If this is not the case, it will be necessary to analyses the section along the river bed where distinct improvement of the conditions should be achieved by calibrating Manning coefficient. Also, all structure along the river is checked, that means all necessary hydraulic structures that are affecting significantly the hydraulic conditions and regime of the river are considered in the model. In addition, to obtain the same simulated discharges with observed ones at gauging stations and to get the full picture of the hydraulic regime of the river effluents, which contributing on the total flow discharge of the Loire River are considered as well. Flow amounts provided by each effluent are equal to the flow rate observed in the corresponding measurement at each respective gauge station.

\section{Results and discussion}

\subsection{Calibration of initial geometry}

The initial geometry of the river is interpolated in several sections at the particular distance between them to obtain a representative simulated water level compare with the observed one. In this context, it is decided to interpolate all sections that need to be simulated with $\Delta x=500 \mathrm{~m}$ since in these ranges high variations of the water level may occur within the $x$-direction. Before running the unsteady analysis, several check and proper correction are performed. During the several tests, an error is identified concerning to the elevation of free water surface at one of the considered station. Indeed, the absolute level is not known and what was only known is a relative datum, which is about $180 \mathrm{~m}$. Due to this uncertainty, this station is not considered during the analysis and calibration.

Differences between the actual cross-section of the gauge stations and particular section in HEC-RAS sometimes are too high. For example, the original part of the Gilly station is at a distance of $10.3 \mathrm{~km}$ upstream (in HEC-RAS is section 91.4). In addition, at Fourneau station is noticed an error in distance, typically this station in HEC-RAS has to be $3.2 \mathrm{~km}$ downstream (i.e. in HEC-RAS model is section 76). In the case of long distance, it is necessary to raise the side of the free surface simulated in another section, closer to the actual gauge station. 
It is assumed that the distance is not too long (less than $\Delta x=1 \mathrm{~km}$ ), so the same parameters are considered in this case. The representative cross-section after interpolation and unsteady analysis are presented in Fig. 2.
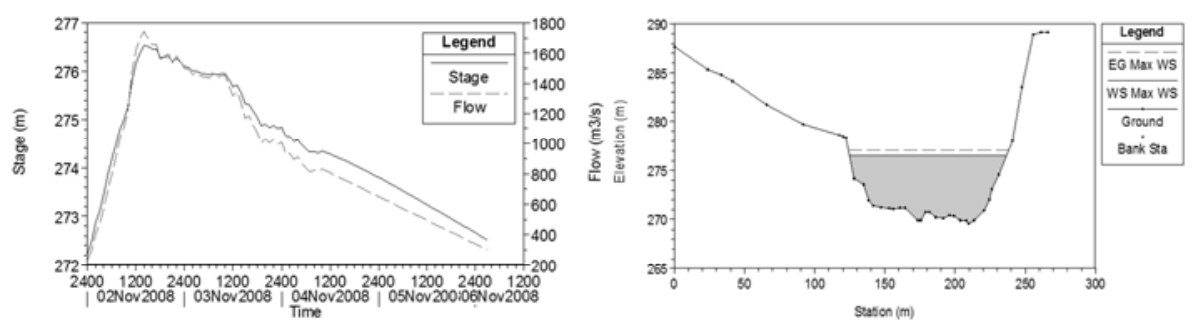

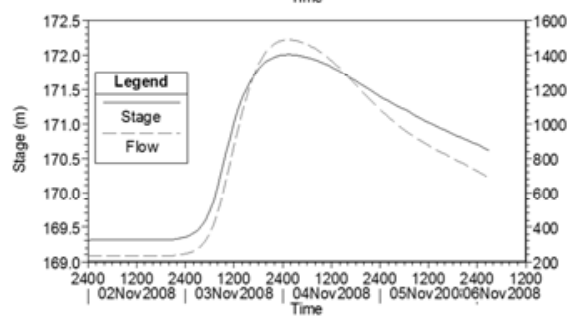

a)

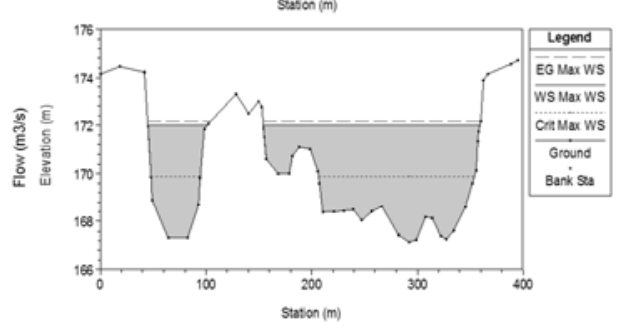

b)

Fig. 2. Representation of a) left first upper, hydrograph at initial upstream part, left second down, hydrograph at closing downstream b) right first upper, cross-section at initial upstream, and right second down, cross-section at the end of the downstream

As it is shown, maximum flow discharge at initial stage regarding upstream part is about $1700 \mathrm{~m}^{3} / \mathrm{s}$, while the water level is about $277 \mathrm{~m}$ (a.s.1). On the other hand, maximum flow discharge at closing stage regarding the downstream part of the river is about $1500 \mathrm{~m}^{3} / \mathrm{s}$, whereas water level is about $172 \mathrm{~m}$ (a.s.l). It is deduced that there is a reduction of flow discharge at the closing stage, this happens due to the allocation; part of the water amount in ineffective areas. This phenomenon is often in the case if the riverbed slope is not too steep; the same situation is discussed in this study. A detailed presentation of the flow discharge and hydraulic depth for the particular sections along the total length of the riverbed is given in Fig. 3.

Regarding the figure above, $0 \mathrm{~m}$ distance represent closing stage at the downstream part while $200000 \mathrm{~m}$ initial stage at the upstream part. There is a significant fluctuation of the flow discharge and hydraulic depth along the riverbed. Since the length of the river is too large, the reason for the variation along the riverbed is mostly due to the morphology of the river, which is very variable [30], [31], [32]. Concerning to the river bed morphology, upstream part is characterized by high diversity; this is evident since along this section of the riverbed there is a significant fluctuation of the flow discharge and hydraulic depth as well. 


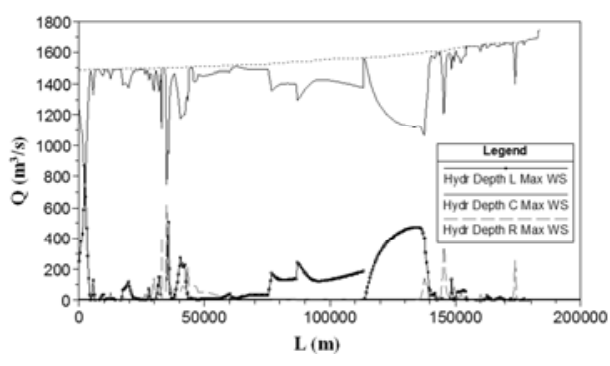

a)

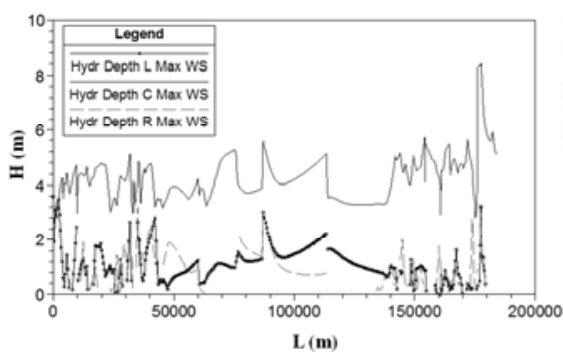

b)

Fig. 3. Representation of a) flow discharge and b) hydraulic depth along the middle part of Loire River

Concerning to the flow regime, Froude number (3) is investigated along with all length of the riverbed in the middle part of Loire River,

$$
F_{r}=\frac{V}{\sqrt{g h}},
$$

where $F_{r}$ is the Froude number, $V[\mathrm{~m} / \mathrm{s}]$ is the water velocity, $g\left[\mathrm{~m} / \mathrm{s}^{2}\right]$ is the gravitational acceleration, and $h[\mathrm{~m}]$ is the hydraulic depth. Detailed information about Froude number (i.e. hydraulic regime) along the riverbed gives in Fig. 4. Concerning to the flow regime, three cases can be classified [23], [33], $F_{r}=1$ is critical flow; $F_{r}>1$ is supercritical flow; $F_{r}<1$ is subcritical flow. As it shown above there are identified two cases where a high value of Froude number occurs, one case is taking place at a distance $150000 \mathrm{~m}$ upstream, where Froude number it is about 0.75 and the second case occurs at a distance less than $50000 \mathrm{~m}$ downstream, where Froude number it is about 0.85 .

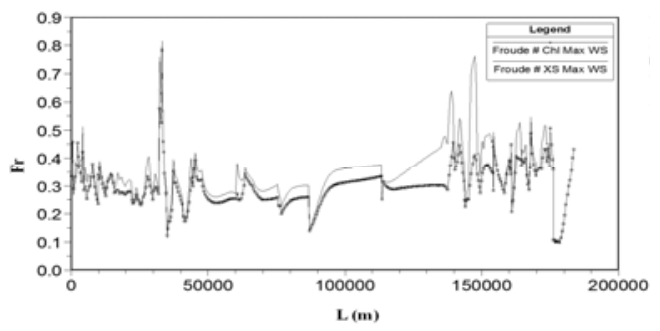

Fig. 4. Froude number along the riverbed

However, in both cases, Froude number is less than one, so the middle part of Loire River demonstrates subcritical regime, that regime leads to law hazard index during the flood events. In addition, velocity distribution is investigated along the riverbed by using (4), 


$$
V=\frac{Q}{A_{\text {slice }}},
$$

where $\mathrm{V}[\mathrm{m} / \mathrm{s}]$ is the mean velocity; $\mathrm{Q}\left[\mathrm{m}^{3} / \mathrm{s}\right]$ is the flow discharge; and $A_{\text {slice }}\left[\mathrm{m}^{2}\right]$ is the area of the individual cross-section slice. In the context of wave propagation, velocity distribution for the initial stage at the upstream part and closing stage downstream part are presented in Fig. $5 a$ and Fig. 5 b.

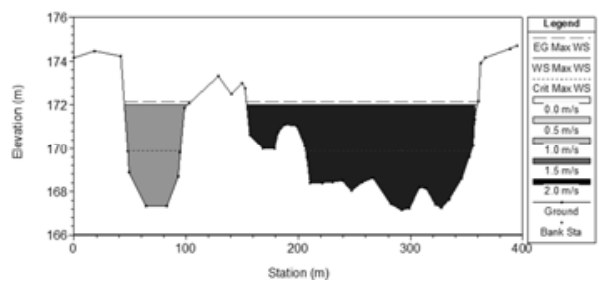

a)

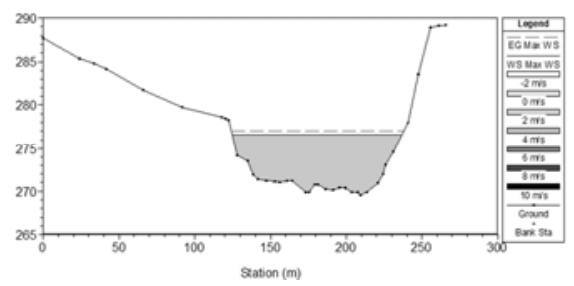

b)

Fig. 5. Representation of a) velocity distribution at initial stage downstream, b) velocity distribution at closing stage upstream

It is noticed that there is a reduction of the velocity distribution within the hydraulic depth at closing stage downstream part compare with velocity distribution at initial stage upstream part. The decrease of velocity within the hydraulic depth at end stage downstream part leads to the mitigation of the flood wave [34].

\subsection{Impact of implemented hydraulic structures}

To perform accurate unsteady state analysis and to validate the calibrated model, except interpolation between sections and changing of Manning coefficient, only hydraulic structures located at an upstream and downstream part of the river as it is shown in Fig. 6, are considered in this model.

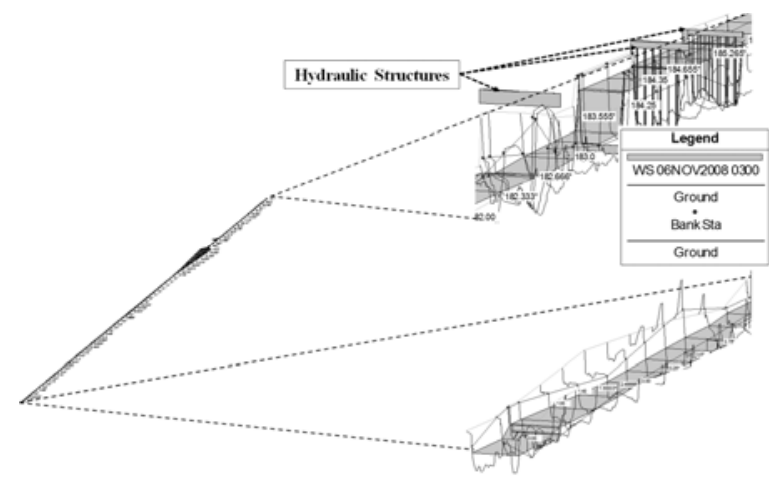

Fig. 6. Implementation of hydraulic structures at upstream (upper part) and downstream (lower part) of Loire River 
There are many bridges and dams implemented along the Loire River, but in the HEC-RAS model, only the hydraulic structures that could affect the water level are considered. However, it is observed that there are not any significant differences. Summary of the Manning coefficients calibrated for different sections; hydraulic structures included in the model and result of water level observed and simulated can be seen in Table $I$.

\section{Table I}

Summary of sections where are made individual calibration regarding Manning coefficient, hydraulic structures considered in the model and results of observed and simulated water levels

\begin{tabular}{|c|c|c|c|}
\hline Sections & $\begin{array}{c}\text { Manning } \\
\text { Coefficient } \\
\text { (main channel) }\end{array}$ & $\begin{array}{c}\text { Implanted } \\
\text { Structures } \\
\left(\mathrm{N}^{\circ} \text { of section in }\right. \\
\text { HEC-RAS })\end{array}$ & $\begin{array}{l}\text { Difference between } \\
\text { simulated and } \\
\text { observed water level } \\
\text { (m) }\end{array}$ \\
\hline $0 \div 7$ & $0.025 \div 0.04$ & $\begin{array}{c}\text { Section } 1.3 \\
\text { Inline structure }\end{array}$ & $\begin{array}{c}\text { Section } 4 \\
171.76-171.59=0.17\end{array}$ \\
\hline $7.5 \div 36.805$ & $0.03 \div 0.05$ & - & - \\
\hline $37 \div 69.5$ & $0.04 \div 0.05$ & - & $\begin{array}{c}\text { Section: } 37.63 \\
187.74-187.85=-0.11\end{array}$ \\
\hline $70 \div 91$ & $0.035 \div 0.05$ & - & $\begin{array}{c}\text { Section: } 79(76)^{*} \\
\text { 202.82-202.76=0.06 }\end{array}$ \\
\hline $91.4 \div 119$ & $0.03 \div 0.05$ & $\begin{array}{c}\text { Section } 91.4 \\
\text { Inline structure }\end{array}$ & $\begin{array}{c}\text { Section: } 81(91.4)^{*} \\
211.09-211.02=0.07\end{array}$ \\
\hline $119.12 \div 184.25$ & $0.03 \div 0.045$ & $\begin{array}{l}\text { Section } 119.12 \\
\text { Bridge }\end{array}$ & $\begin{array}{c}\text { Sections: } 119.24 \\
224.59-224.6=-0.01\end{array}$ \\
\hline $184.35 \div 191.7$ & $0.03 \div 0.05$ & - & $\begin{array}{c}\text { Section: } 119.24 \\
268.96-268.93=0.03\end{array}$ \\
\hline
\end{tabular}

The hydraulic structure that is necessary to be implemented in the HEC-RAS model is determined from Geoportal site. Bridges with an abutment and inline structure as it is shown in Fig. 7 represent the type of hydraulic structures included in the model.

It is noticed that the Manning coefficient has a less effect on water levels than hydraulic structures such as inline structures. So small floodplain does not contribute too much on water level fluctuation, in these conditions, all values of Manning coefficient are considered $\geq 0.04$.

\subsection{Validation and calibration by using low flow data}

Further calibration and validation of the model developed in HEC-RAS are done by using another set of data (i.e. low flow data), based on 2011-2012 records. Whereas low flow data are introduced at, each respective effluents, and accurate simulation are performed to notice any possible differences between observed and simulated water levels. Information about observed, simulated water levels, absolute differences occurred after calibration and validation of the model are presented in Table II. 

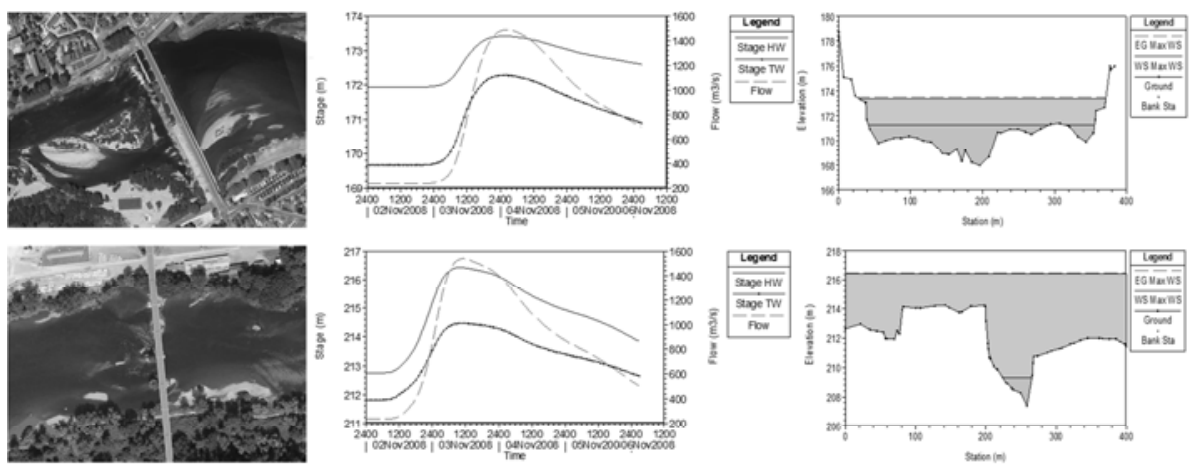

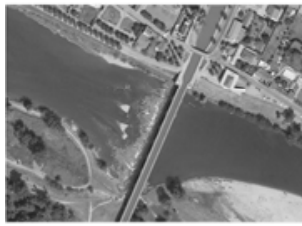

a)

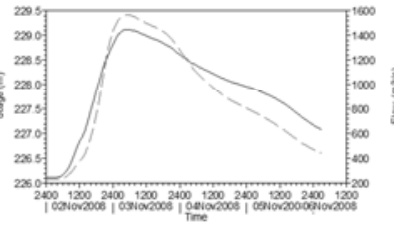

b)
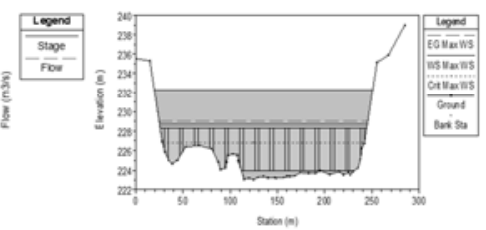

c)

Fig. 7. Representation of a) top view of hydraulic structures from Geoportal (sources: https://www.geoportail.gouv.fr), b) hydrograph stage and flow for individual data at given structure, c) hydraulic structure implemented in the model

Table II

Differences between observed and simulated water level for low flow data

\begin{tabular}{|c|c|c|c|}
\hline Stations & $\begin{array}{c}\text { Observed water level } \\
(\mathrm{m})\end{array}$ & $\begin{array}{c}\text { Simulated water level } \\
(\mathrm{m})\end{array}$ & $\begin{array}{c}\text { Differences } \\
(\mathrm{m})\end{array}$ \\
\hline Nevers & 171.58 & 171.57 & 0.01 \\
Decize & 187.83 & 187.64 & 0.15 \\
Fourneau & 202.72 & 202.79 & 0.07 \\
Gilly & 210.99 & 211.04 & -0.05 \\
Digoin & 224.58 & 224.57 & 0.01 \\
Villerest & 268.72 & 268.66 & 0.06 \\
(downstream) & & & \\
\hline
\end{tabular}

As it is shown in Fig. 8 it is noticed that differences between observed and simulated water levels are increasing from upstream to downstream part, this phenomenon may happen because of rising floodplain.

Since the floodplain is growing, this leads to the increase of uncertainty that is caused mostly by the geomorphological condition of the riverbed. However, after validation of the model, it is concluded that maximum differences between observed and simulated water level are about $15 \mathrm{~cm}$; the results are satisfactory and reasonable. Note that; data used to conduct the model validation are obtained mainly from the low flow event, so to have a model that works in all cases; further simulation has to be performed by considering different flood events in combination with low flow event. 


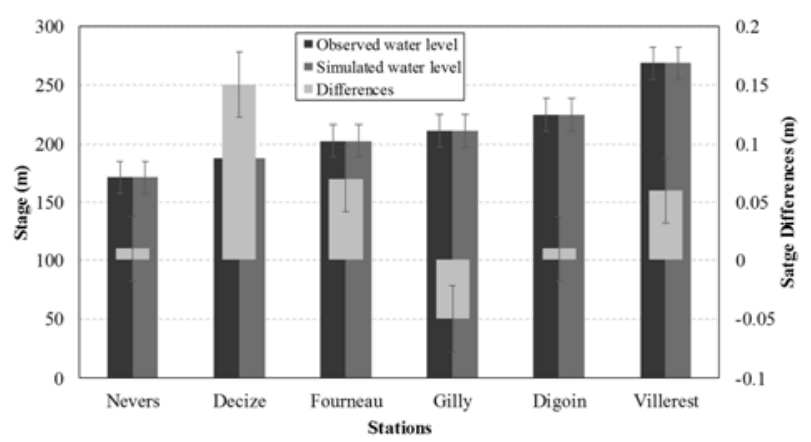

Fig. 8. Representation of differences between observed and simulated water level

\section{Conclusions}

To understand the hydraulic regime of the natural stream is imperative to have as much as accurate possible information about the geomorphology of the river bed within the cross-section and longitudinal section as well. Investigation of the hydraulic regime has been done by performing a certain number of simulations at a middle part of the Loire River. For this purpose, two different flow dataset are used. In addition, since Loire River is characterized by significant variability concerning to the geomorphological condition, proper calibration regarding Manning coefficient are performed. The maximum variation of Manning coefficient considered for different sections along the longitudinal profile of the river bed varies between 0.04-0.06. The highest value of the Manning coefficient is found only for cases where significant meandering of the riverbed is noticed. After precise calibration regarding the Manning coefficient along the riverbed, also, some of the primary hydraulic structures that may affect the water levels are included in the model. Considering first data set (i.e. flood event), several simulations are performed where sub-critical flow regime is noticed. Water levels obtained after modeling and simulations are compared with observed water levels obtained from gauge station at Loire River. Comparison of both levels shows that there are not too high differences between them. Further simulation is performed by considering second data set (i.e. low flow). The water levels difference between observed and simulated ones is about $0.15 \mathrm{~m}$. While the comparison of the results obtained from both cases shows that differences of observed with simulated water levels in the first instance (i.e. flood event) are less than second case (i.e. low flow). So to obtain results that are more accurate and information about the hydraulic regime of the river, further modeling and simulation may be needed by considering additional data set (i.e. flood events in combination with low flow phenomena).

\section{References}

[1] Poff N. L., Allan J. D., Bain M. B., Karr J. R., Prestegaard K. L., Richter B. D., Stromberg J. C. The natural flow regime, BioScience, Vol. 47, No. 11, 1997, pp. 769-784. 
[2] Olden J. D., Poff N. L. Redundancy and the choice of hydrologic Indices for characterizing stream flow regimes, River Research and Applications, Vol. 19, No. 2, 2003, pp. 101-121.

[3] Sanford S. E., Creed I. F., Tague C. L., Beall F. D., Buttle J. M. Scale-dependence of natural variability of flow regimes in a forested landscape, Water Resources Research, Vol. 43, No. 8, 2007, pp. 1-15.

[4] De Doncker L., Troch P., Verhoeven R., Bal K., Meire P., Quintelier J. Determination of the Manning roughness coefficient influenced by vegetation in the river Aa and Biebrza river, Environmental Fluid Mechanics, Vol. 9, No. 5, 2009, pp. 549-567.

[5] Kelčík S., Pindjakova T., Šoltész A. Assessment and design of the flood protection measures in the district of Levice (Slovakia), Pollack Periodica, Vol. 11, No. 1, 2016, pp. 35-41.

[6] Pindjakova T., Kelčík S., Šoltész A. Simulation of flood progress on the River Gidra, Pollack Periodica, Vol. 11, No. 1, 2016, pp. 25-34.

[7] Moncoulon D., Labat D., Ardon J., Leblois E., Onfroy T., Poulard C., Quantin A. Analysis of the French insurance market exposure to floods: A stochastic model combining river overflow and surface runoff, Natural Hazards and Earth System Sciences, Vol. 14, No. 9, 2014, pp. 2469-2485.

[8] Selenica A., Kuriqi A., Ardicioglu M. Risk assessment from flooding's in the rivers of Albania, $I^{\text {st }}$ International Balkans Conference on Challenges of Civil Engineering, Tirana, Albania, 5-9 May 2011, pp. 45-51.

[9] Grover P., Naumov A., Khayer Y. Comparison of 1D and 2D models for dam break flow: Simulations for two different river systems, Trades Union Congress, Bournemouth, England, 1-11 September 2013, pp. 47-52.

[10] Prastacos P., Prinet V. ANFAS: a decision support system for simulating river floods, Proceedings of the 7th AGILE Conference on Geographic Information Science, Heraklion, Greece, 28-29 April 2004, pp. 63-72.

[11] Spada E., Sinagra M., Tucciarelli T., Biondi D. Unsteady state water level analysis for discharge hydrograph estimation in rivers with Torrential Regime: The case study of the February 2016 flood event in the Crati River, South Italy, Water, Vol. 9, No. 4, 2017, pp. 1-15.

[12] Siegle E., Schettini C. A., Klein A. H., Toldo Jr E. E. Hydrodynamics and suspended sediment transport in the Camboriú estuary - Brazil: pre jetty conditions, Brazilian Journal Oceanography, Vol. 57, No. 2, 2009, pp. 12-135.

[13] Dos Santos P. P., Tavares A. O. Basin flood risk management: a territorial data-driven approach to support decision-making, Water, Vol. 7, No. 2, 2015, pp. 480-502.

[14] Middelkoop H., Daamen K., Gellens D., Grabs W., Kwadijk J. C., Lang H., Wilke K. Impact of climate change on hydrological regimes and water resources management in the Rhine Basin, Climatic Change, Vol. 49, No. 1-2, 2001, pp. 105-128.

[15] Latapie A., Camenena B., Rodrigues S., Paquier A., Bouchard J. P., Moatar F. Assessing channel response of a long river influenced by human disturbance, Catena, Vol. 121, 2014, pp. 1-12.

[16] Kuriqi A., Ardiçlioglu M., Muceku Y. Investigation of seepage effect on river dike's stability under steady state and transient conditions, Pollack Periodica, Vol. 11, No. 2, 2016, pp. 87-104.

[17] Du S., Gu H., Wen J., Chen K., Van Rompaey A. Detecting flood variations in Shanghai over 1949-2009 with Mann-Kendall tests and a newspaper-based database, Water, Vol. 7, No. 5, 2015, pp. 1808-1824.

[18] Magnier B., Claude N., Villaret C., Rodrigues S., Tassi P. Numerical simulation of flow structures in the presence of alternate and transverse bars: Application to the Loire River (France), Trades Union Congress, Bournemouth, England, 1-11 September 2013, pp. 16-31. 
[19] Gourry J. C., Vermeersch F., Garcin M., Giot D. Contribution of geophysics to the study of Alluvial Deposits: A case study in the Val d'Avaray area of the River Loire, France, Journal of Applied Geophysics, Vol. 54, No. 1-2, 2003, pp. 35-49.

[20] Coeur D., Djerboua A. The 1856 flood: Reconstruction and analysis of a reference hydrological event, La Houille Blanche, International Water Journal, No. 2, 2007, pp. 27-37.

[21] Bourgin F. Calibration of a catchment-based land surface model in the Loire River basin (France) to assess hydrological impacts of climate change, Master Thesis, Environmental Engineering, Technische Universitat Munchen, 2009.

[22] Heimhuber V., Hannemann J. C., Rieger W. Flood risk management in remote and impoverished areas - a case study of Onaville, Haiti, Water, Vol. 7, No. 7, 2015, pp. 3832-3860.

[23] Poff N. L., Olden J. D., Pepin D. M., Bledsoe B. P. Placing global stream flow variability in geographic and geomorphic contexts, River Research and Applications, Vol. 22, No. 2, 2006, pp. 149-166.

[24] Moulin L., Gaume E., Obled C. Uncertainties on mean areal precipitation: Assessment and impact on stream flow simulations, Hydrology and Earth System Sciences, Vol. 2, No. 13, 2009, pp. 99-114.

[25] Timbadiya P. V., Patel P. L., Porey P. D. Calibration of HEC-RAS model on the prediction of flood for lower Tapi River, India, Journal of Water Resource and Protection, Vol. 3, No. 11, 2011, pp. 805-811.

[26] Moussa R., Bocquillon C. Criteria for the choice of flood-routing methods in natural channels, Journal of Hydrology, Vol. 186, No. 1-4, 2004, pp. 1-30.

[27] Ardiclioglu M., Selenica A., Ozdin S., Kuriqi A., Genç O. Investigation of average shear stress in natural stream, $I^{\text {st }}$ International Balkans Conference on Challenges of Civil Engineering, Tirana, Albania, 5-9 May 2011, pp. 8-16.

[28] Timbadiya P. V., Patel P. L., Porey P. D. Calibration of HEC-RAS Model on the prediction of flood for lower Tapi River, India, Journal of Water Resource and Protection, Vol. 3, No. 11, 2011, pp. 805-811.

[29] Gaume E., Livet M., Desbordes M., Villeneuve J. P. Hydrological analysis of the river Aude, France, a flash flood on 12 and 13 November 1999, Journal of Hydrology, Vol. 286, No. 1, 2004, pp. 135-154.

[30] Mohammadi S., Kashefipour S. M. Numerical modeling of flow in riverine basins using an improved dynamic roughness coefficient, Water Resources, Vol. 41, No. 4, 2014, pp. $412-420$.

[31] Miyab N. M., Afzalimehr H., Singh V. P., Ghorbani B. On flow resistance due to vegetation in a Gravel-Bed River, International Journal of Hydraulic Engineering, Vol. 3, No. 3, 2014, pp. 85-92.

[32] Yang Z., Wang T., Khangaonkar T., \& Breithaupt S. Integrated modeling of flood flows and tidal hydrodynamics over a coastal floodplain, Environmental Fluid Mechanics, Vol. 12, No. 1, 2012, pp. 63-80.

[33] Grant G. E. Critical flow constrains flow hydraulics in mobile-bed streams: A new hypothesis, Water Resources Research, Vol. 33, No. 2, 1997, pp. 349-358.

[34] Saltzer R. L., Humphreys E. D. Upper mantle P wave velocity structure of the eastern Snake River Plain and its relationship to geodynamic models of the region, Journal of Geophysical Research, Vol. 102, No. B6, 1997, pp. 11829-11841. 